\title{
Forest impacts on snow accumulation and ablation across an elevation gradient in a temperate montane environment
}

\author{
Travis R. Roth and Anne W. Nolin \\ Water Resource Sciences, Oregon State University, Corvallis, OR 97331, USA \\ Correspondence to: Travis R. Roth (rothtra@science.oregonstate.edu)
}

Received: 5 October 2016 - Discussion started: 1 November 2016

Revised: 5 September 2017 - Accepted: 9 September 2017 - Published: 6 November 2017

\begin{abstract}
Forest cover modifies snow accumulation and ablation rates via canopy interception and changes in subcanopy energy balance processes. However, the ways in which snowpacks are affected by forest canopy processes vary depending on climatic, topographic and forest characteristics. Here we present results from a 4-year study of snow-forest interactions in the Oregon Cascades. We continuously monitored snow and meteorological variables at paired forested and open sites at three elevations representing the Low, Mid, and High seasonal snow zones in the study region. On a monthly to bi-weekly basis, we surveyed snow depth and snow water equivalent across $900 \mathrm{~m}$ transects connecting the forested and open pairs of sites. Our results show that relative to nearby open areas, the dense, relatively warm forests at Low and Mid sites impede snow accumulation via canopy snow interception and increase sub-canopy snowpack energy inputs via longwave radiation. Compared with the Forest sites, snowpacks are deeper and last longer in the Open site at the Low and Mid sites (4-26 and 11-33 days, respectively). However, we see the opposite relationship at the relatively colder High sites, with the Forest site maintaining snow longer into the spring by 15-29 days relative to the nearby Open site. Canopy interception efficiency $\left(C_{\mathrm{IE}}\right)$ values at the Low and Mid Forest sites averaged 79 and $76 \%$ of the total event snowfall, whereas $C_{\mathrm{IE}}$ was $31 \%$ at the lower density High Forest site. At all elevations, longwave radiation in forested environments appears to be the primary energy component due to the maritime climate and forest presence, accounting for 93, 92, and $47 \%$ of total energy inputs to the snowpack at the Low, Mid, and High Forest sites, respectively. Higher wind speeds in the High Open site significantly increase turbulent energy exchanges and snow sublimation. Lower wind speeds in the High Forest site create
\end{abstract}

preferential snowfall deposition. These results show the importance of understanding the effects of forest cover on subcanopy snowpack evolution and highlight the need for improved forest cover model representation to accurately predict water resources in maritime forests.

\section{Introduction}

Snowpacks the world over are changing. Increasing global temperatures and accompanied climatic changes are altering snowpack characteristics and shifting melt timing earlier (McCabe and Clark, 2005; Mote, 2006; Mussleman et al., 2017). The timing, intensity, and duration of snowmelt depend on climatic and physiographic variables. In the topographically diverse western US the distribution of snow cover is governed by regional climate, elevation, vegetation presence/absence, and forest structure (Elder et al., 1998; Harpold et al., 2013). Forests overlap with mountains across this region and modify snow accumulation and ablation rates through canopy interception and a recasting of the sub-canopy energy balance (Hedstrom and Pomeroy, 1998; López-Moreno and Stähli, 2008; Varhola et al., 2010). Recently, a considerable amount of effort has been expended in research into the snow-forest processes that control the distribution of snow in mountainous regions (Stähli and Gustafsson, 2006; Jost et al., 2007; López-Moreno and Latron, 2008; Musselman et al., 2008; Ellis et al., 2013; Moeser et al., 2015). While these studies have focused on cold, predominately continental snowpacks, few have investigated snow-forest process interaction in warm maritime environments where snow is especially sensitive to changes in energy balance (Storck et al., 2002; Lundquist et al., 2013). 
Maritime snowpacks accumulate and reside at temperatures near the melting point. Such snowpacks do not fit the simple accumulation-ablation model of a monotonic increase until peak snow water equivalent (SWE) followed by a monotonic decrease to snow disappearance. Such temperature sensitive snowpacks may experience disproportionate effects of climate warming and changing forest cover (Nolin and Daly, 2006; Dickerson-Lange et al., 2015). Ramifications of these impacts have far reaching eco-hydrological impacts across the snowmelt dependent western US, highlighting the continued need for research into snow-forest process interactions in maritime montane settings (Mote, 2006; Harpold et al., 2015; Vose et al., 2016).

In the Pacific Northwest, United States (PNW), mountain environments are a disparate composite of forest cover driven by forest harvest, regrowth, and natural disturbance. Forest disturbance can have significant impacts on snow processes, whose effects can range from immediate (Boon, 2009) to decadal (Lyon et al., 2008; Gleason and Nolin, 2016). At the stand scale, forests attenuate wind speeds, thereby suppressing turbulent mixing of the near-surface atmosphere (Liston and Sturm, 1998); modify the radiation received at the snow surface through shifts in shortwave and longwave contributions and reduced surface albedo (Sicart et al., 2004; O'Halloran et al., 2012; Gleason et al., 2013); and temporally shift seasonal- and event-scale accumulation and ablation patterns through canopy snowfall interception (Varhola et al., 2010). Natural and anthropogenic alterations in forest cover such as mountain pine beetle infestation, forest management practices, and forest fire affect snow processes by modifying forest structure, i.e., canopy cover and gap size (Boon, 2009; Bewley et al., 2010; Ellis et al., 2013) and snow albedo (Gleason et al., 2013; Gleason and Nolin, 2016). The frequency and intensity of forest fires have been increasing (Westerling et al., 2006; Miller et al., 2009; Spracklen et al., 2009), impacting accumulation and ablation rates (Gleason et al., 2013), and are anticipated to continue increasing (Moritz et al., 2012; Westerling et al., 2011), while prolonged droughts, and a future of increasing drought prevalence, have increased water stress, creating changes in forest characteristics across the western US (Allen, 2010; Choat, 2012; Dai, 2013). Disturbances of this type alter the snowforest dynamic through a modification of the magnitudes of central process relationships, often resulting in unanticipated outcomes (Lundquist et al., 2013). The present reality and specter of continued future change to climate and forest cover underscores the increasing importance of characterizing vegetation impacts on snow accumulation and ablation within warm, topographically varied terrains.

Elevation (as a proxy for temperature) and forest canopy cover are important controls on peak snow accumulation (Geddes et al., 2005; Jost et al., 2007). Elevation drives snow accumulation and is the principle predictor of peak snow water equivalent (Gray, 1979; Elder et al., 1991; Sproles et al., 2013). The partitioning of precipitation between rainfall and snowfall is determined by atmospheric temperature and the elevation of the rain-snow transition can be described as a function of the temperature lapse rate. Forest canopies intercept snow, reducing sub-canopy accumulation (Schmidt and Gluns, 1991; Hedstom and Pomeroy, 1998; Musselman et al., 2008). The magnitude and rate of canopy interception are also affected by air temperature. Air temperature has been shown to have an inverse relationship with canopy interception (Andreadis et al., 2009) and a nonlinear correlation with event size (Hedstrom and Pomeroy, 1998); these relationships are often based on a few measurements and at a single point. Forests also reduce solar radiation reaching the snowpack surface (Link and Marks, 1999; Hardy et al., 2004) and increase longwave radiation at the snowpack surface (Lundquist et al., 2013), thus modifying net radiation (Sicart et al., 2004). Forest cover reduces wind speed, thereby reducing latent and sensible heat flux at the snowpack surface (Link and Marks, 1999; Boon, 2009). The direct effect of wind speed on canopy snow interception has not been explicitly studied, with most research focusing on wind redistribution of snow (Gary, 1974; Pomeroy et al., 1997; Liston and Sturm, 1998; Woods et al., 2006). Research demonstrates that forests reduce wind speed and can lead to increased snow accumulation in canopy gaps or forest clearcuts where wind speeds decline and snow is released from upwind canopy flow (Gary, 1974). These combined forest effects on sub-canopy energy and mass balance can accelerate or delay the onset and rate of snowmelt (Varhola et al., 2010). These studies highlight the key differences between forested and open areas, and the effects of elevation on snowpack evolution. With strong agreement that the western US will be facing warmer winters in the future and new understanding that snow in forested regions is more sensitive to increased temperatures than snow in non-forested regions (Lundquist et al., 2013), it is critical that we measure, characterize, and understand maritime snow-forest interactions. This study examines and evaluates the combined effects of forest cover, climate variability, and elevation on snow accumulation and ablation in a maritime montane environment. Specifically, we focus on the following research questions.

1. To what extent do forests modify snow accumulation and ablation in a maritime temperate forest?

2. How does canopy interception affect sub-canopy snowpack evolution across an elevation gradient?

3. How does forest cover affect the sub-canopy snow surface energy balance relative to adjacent open areas and what are the principal drivers of melt?

In subsequent sections, we describe the study area; present research methods for field measurements, energy balance calculations, and snow modeling; present our key findings; and conclude with a description of potential applications and future steps. 


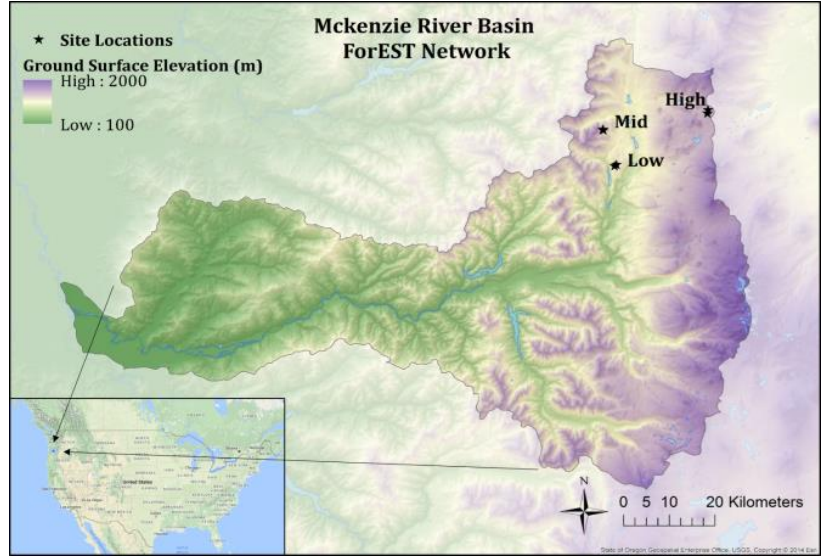

Figure 1. The Oregon ForEST network sites of the McKenzie River basin.

\section{Methods}

\subsection{Description of the study area}

The McKenzie River basin (MRB) is part of the greater Willamette River basin in western Oregon, USA (Fig. 1). It covers an area of $3041 \mathrm{~km}^{2}$ and spans an elevation range from $150 \mathrm{~m}$ to over $3100 \mathrm{~m}$ at the crest of the Cascades Mountains that flank its eastern boundary. Orographic uplift results in average annual precipitation ranging from $1000 \mathrm{~mm}$ at lower elevations to over $3500 \mathrm{~mm}$ at the highest elevations in the basin (Jefferson et al., 2008). The rain-snow transition zone sits between 500 and $1200 \mathrm{~m}$ (Marks et al., 1998). The area above the transition zone accounts for $12 \%$ of the total area with the Willamette River basin, yet contributes $60-80 \%$ of summer baseflow to the Willamette River (Brooks et al., 2012). The MRB elevation between 1000 and $2000 \mathrm{~m}$ is especially important as it comprises $42 \%$ of the total area within the MRB and snowmelt from this elevation band accounts for nearly $93 \%$ of the total snow water storage (Sproles et al., 2013). Warm snowpack conditions facilitate frequent melt events during the winter months of December, January and February (DJF), commonly masking the distinction between accumulation and ablation periods. Nolin and Daly (2006) showed that snowpack in this region has an acute sensitivity to temperature, with the low elevation snow zones of the Oregon Cascades classified as the most "at-risk" snow within the region. The Natural Resources Conservation Service (NRCS) has been monitoring seasonal snowpack within the MRB since the early 1980s by a point-based snow telemetry (SNOTEL) network. Placement of SNOTEL stations was designed to be representative of water producing regions of a watershed and yet network stations were ultimately placed in protected, accessible locations (Molotch and Bales, 2006). However, the limited configuration was not designed to understand forest-snow processes or with future climate change in mind, and therefore a statistically unbiased approach to site selection that is spatially representative is needed for any substantial snow observation network (Molotch and Bales, 2006). This underscores the need for intelligent and statistically relevant snow monitoring sites that go beyond the existing network. Section 2.2 outlines the snow monitoring network we deployed in water year (WY) 2012 that meets these stated needs.

\subsection{The Oregon ForEST network}

The Oregon Forest Elevation Snow Transect (ForEST) network extends from the rain-snow transition zone through the seasonal snow zone in the Oregon Cascades with paired forested and open sites at three elevations, Low $(1150 \mathrm{~m})$, Mid (1325 m) and High (1465 m) (Fig. 1). The ForEST network was designed to efficiently represent the range of peak SWE within the basin. Using a binary regression tree (BRT) approach, we identified elevation, vegetation type and vegetation density as the key predictor variables and we used them to classify the basin and locate our network sites (Molotch and Bales, 2006; Gleason et al., 2017). At each of three elevation zones, we established Open (low forest density) and Forest (high forest density) site pairs in adjacent areas, while controlling for slope and aspect. Open sites consisted of $<20 \%$ canopy cover, while corresponding Forest sites had $>60 \%$ canopy cover based on the 2001 National Vegetation Cover Database (Homer et al., 2007), and were subsequently verified by in situ measurements.

At each of the six sites within the ForEST network towerbased instruments continuously measured snow depth, incoming and reflected shortwave radiation, air temperature, relative humidity, wind speed, wind direction, and soil temperature and soil moisture (Table S1 in the Supplement). Sensor measurement frequency was $15 \mathrm{~s}$ with output values averaged over a $10 \mathrm{~min}$ period. The suite of sensors allowed the calculation of the snow surface energy balance through either direct measurement, e.g., solar radiation, or empirical equations, e.g., turbulent fluxes or longwave radiation. The snow-climate monitoring stations were deployed and active for the duration of the snow season at all sites, typically from mid to late November through May, with minimal disruptions due to battery or mechanical failures. We present results from the Low and Mid sites for WY 2012-WY 2015 and results from the High sites which were added to the network for WY 2014 and WY 2015. Additionally, SWE and snow depth measurements were collected along $900 \mathrm{~m}$ transects ("snow courses") extending from the Forest to Open sites in the low, mid, and high elevation zones. SWE measurement locations were restricted to $>50 \mathrm{~m}$ from the forest edge to eliminate canopy edge effects. These snow course surveys were conducted on a monthly basis during the accumulation period, and then bi-weekly during the ablation phase until the snow disappearance date (SDD). SWE was measured using a snow tube (Federal sampler) and snow depth was measured using a steel probe pole. Within each vegetation cover type, 
e.g., Open or Forest sites, SWE measurements were made at $100 \mathrm{~m}$ intervals with snow depth measurements every $5 \mathrm{~m}$. Snow course data used in this analysis are from WY 2012 to WY 2015 for all ForEST network sites. To estimate SDD for each site we calculated the snowpack ablation rate using median snow depths from the last two snow courses of the season and linearly extrapolating to the date of zero snow depth. SDD represents the date when the primary seasonal snowpack disappears and does not take into account late season periods of accumulation/ablation. We excluded data from the historically low WY 2015 due to a near absence of winter snow.

\subsection{Canopy interception efficiency}

Forest structure characteristics at each site were quantified using ground-based conventional forest inventory methods. At transect locations coinciding with SWE measurements, individual tree characteristics were measured within each quadrat and averaged for that particular site, i.e., diameter at breast height $(\mathrm{DBH})$, crown radius, tree height, and tree species (Table 1). Forest density was performed using a plotless density estimator approach described in Elzinga et al. (1998). The forest canopy at each site was further characterized using skyward looking hemispherical photographs acquired using a Nikon Coolpix 990 digital camera equipped with a FC-E8 fisheye converter, which has a $180^{\circ}$ field-ofview (Inoue et al., 2004). The hemispherical photographs were assessed with the Gap Light Analyzer 2.0 to measure leaf area index (LAI) and canopy closure (CC), which is the complement of the sky view fraction (Frazer et al., 1999).

During the snow accumulation period forest canopy plays a large role in reducing snowpack by intercepting incoming snowfall, prohibiting a significant portion from accumulating on the forest floor. A forest canopy is the integrated sum of the forest overlaying the ground surface; this includes needles, leaves, branches, and trunks. The canopy structure is the primary control on canopy interception, followed by eventspecific variables, i.e., event size, air temperature, and wind speed (Varhola et al., 2010). Canopy snow interception is inherently difficult to accurately quantify due to the temporally sensitive impacts of local climate on the canopy itself and the limited measurement capabilities to directly measure canopy interception (Martin et al., 2013; Friesen et al., 2014). From measured snowfall at each climate station within the ForEST network we calculated percent canopy interception efficiency $\left(C_{\mathrm{IE}}\right)$ for daily snowfall events. A snowfall event is defined as the daily increase in measured snow depth in the Open sites greater than $3 \mathrm{~cm}$. Ryan et al. (2008) showed that acoustic snow depth measurement error for the Campbell Scientific SR50a is $\pm 2 \mathrm{~cm}$ under normal field conditions. Therefore, to reduce the influence of depth measurement error on our snow event classification, we used $\mathrm{a} \geq 3 \mathrm{~cm}$ threshold for our anal- ysis. $C_{\mathrm{IE}}$ is calculated as

$C_{\mathrm{IE}}=\left[\frac{O_{\mathrm{S}}-F_{\mathrm{S}}}{O_{\mathrm{S}}}\right] \times 100$,

where $O_{\mathrm{S}}$ and $F_{\mathrm{S}}$ are the measured snowfall $(\mathrm{cm})$ in the Open and Forest sites, respectively. $C_{\mathrm{IE}}$ was calculated for individual events and for seasonal averages at each Forest site.

\subsection{Snow surface energy balance}

A snow surface energy balance was calculated at a daily time step using aggregated $10 \mathrm{~min}$ meteorological measurements from each site. Each energy balance component was either directly measured or calculated using empirically derived equations valid for a maritime snowpack. Total energy into the snowpack equals the combined incoming and outgoing energies experienced at the surface of the snowpack. The governing equation for the snow surface energy balance is

$\Delta Q=Q_{\mathrm{S}}+Q_{\mathrm{L}}+Q_{\mathrm{E}}+Q_{\mathrm{H}}+Q_{\mathrm{C}}$

where $\Delta Q$ is the change in total energy present at the snow surface $\left(\mathrm{W} \mathrm{m}^{-2}\right) ; Q_{\mathrm{S}}$ is total solar radiation $\left(\mathrm{W} \mathrm{m}^{-2}\right)$; $Q_{\mathrm{L}}$ is total longwave radiation $\left(\mathrm{W} \mathrm{m}^{-2}\right) ; Q_{\mathrm{E}}$ is latent heat $\left(\mathrm{W} \mathrm{m}^{-2}\right) ; Q_{\mathrm{H}}$ is sensible heat $\left(\mathrm{W} \mathrm{m}^{-2}\right)$; and $Q_{\mathrm{C}}$ is conductive energy $\left(\mathrm{W} \mathrm{m}^{-2}\right)$.

A critical component within the snow surface energy balance calculations is the determination of the snow surface temperature, $T_{\text {snow }}$ (Andreas, 1986). $T_{\text {snow }}$ controls directional energy flows by regulating temperature and vapor flux gradients between the atmosphere and the snowpack, which control the sensible and latent heat transfer, respectively. $T_{\text {snow }}$ is also the primary control of longwave radiation emitted from the snowpack. However, $T_{\text {snow }}$ is difficult to directly measure and is therefore estimated as a function of the dew-point (frost-point) temperature, $T_{\text {dew }}$, as demonstrated by Raleigh et al. (2013). Using $T_{\text {dew }}$ to estimate daily averages of $T_{\text {snow }}$ reduces bias and is a reasonable first-order approximation at standard height measurements (Raleigh et al., 2013).

\subsubsection{Solar radiation}

Incoming and reflected solar radiation were each measured using an upward facing and downward facing LI-200s ${ }^{\mathrm{TM}}$ pyranometer (LI-COR). The pyranometers have a spectral range of 400-1100 $\mathrm{nm}$ and a field-of-view of $180^{\circ}$. Net solar radiation is calculated as

$Q_{\mathrm{S}}=S_{\text {in }} \times(1-\alpha)$

where $S_{\text {in }}$ equals the measured incoming shortwave radiation $\left(\mathrm{W} \mathrm{m}^{-2}\right)$. Albedo, $\alpha$, was calculated as the ratio of reflected and incoming measured solar radiation. When periods of newly fallen snow obscured the upward facing solar pyranometer, i.e., when $\frac{S_{\text {out }}}{S_{\text {in }}}>1$, a value of $\alpha=0.9$ was used. 
Table 1. Site forest characteristics with the associated SD for each measurement.

\begin{tabular}{lrrrrrr}
\hline Site & DBH $(\mathrm{cm})$ & Height $(\mathrm{m})$ & $\begin{array}{r}\text { Crown } \\
\text { diameter }(\mathrm{m})\end{array}$ & $\begin{array}{r}\text { Forest } \\
\text { density } \\
\text { per } 10 \mathrm{~m}^{2}\end{array}$ & $\begin{array}{r}S_{\mathrm{VF}}(\%) \\
\end{array}$ & $\begin{array}{r}\text { Study } \\
\text { duration } \\
\text { average } \\
C_{\mathrm{IE}}(\%)\end{array}$ \\
\hline Low Forest & $52.1 \pm 20.0$ & $33.7 \pm 10.4$ & $9.4 \pm 0.8$ & $19.4 \pm 2.0$ & 10.9 & 79 \\
Low Open & $17.3 \pm 4.3$ & $8.9 \pm 2.6$ & $3.7 \pm 0.4$ & $15.7 \pm 5.1$ & 68.7 & - \\
Mid Forest & $36.5 \pm 17.4$ & $21.2 \pm 10.1$ & $6.7 \pm 0.8$ & $20.7 \pm 1.5$ & 10.1 & 76 \\
Mid Open & $19.0 \pm 8.3$ & $11.8 \pm 3.4$ & $4.0 \pm 0.2$ & $15.8 \pm 6.7$ & 61.6 & - \\
High Forest & $21.4 \pm 4.1$ & $14.2 \pm 3.7$ & $2.8 \pm 0.1$ & $19.0 \pm 12.8$ & 35.1 & 39 \\
High Open* & $29.4 \pm 10.3$ & $9.9 \pm 3.4$ & $0.4 \pm 0.6$ & $13.1 \pm 3.9$ & 88.1 & - \\
\hline
\end{tabular}

* Includes fire related standing dead trees.

Similarly, when $\frac{S_{\text {out }}}{S_{\text {in }}}<0.3$, a value of $\alpha=0.3$ was used to adequately simulate the lower bound of forest floor albedo during the ablation period (Melloh et al., 2002).

\subsubsection{Longwave radiation}

Longwave radiation is rarely directly measured in the seasonal snow zone due to the high cost in both absolute, e.g., instrument cost, and relative terms, e.g., energy requirements. Longwave radiation balance was calculated as

$Q_{\mathrm{L}}=L \uparrow+L \downarrow$

where $L \downarrow$ is the calculated longwave radiation received by the snowpack surface and $L \uparrow$ is the calculated longwave radiation emitted by the snow surface. Longwave radiation emitted at the snow surface is approximated by

$L \uparrow=\varepsilon_{\text {snow }} \sigma T_{\text {snow }}^{4}$

where $\varepsilon_{\text {snow }}$ is the snow surface emissivity and is set at 0.96 (Link and Marks, 1999).

A variety of empirically derived formulas exist for calculating incoming longwave radiation under clear $\left(L_{\text {clear }}\right)$ and cloudy skies at various sites throughout the world (Brutsaert, 1975; Sicart et al., 2004; Flerchinger et al., 2009). All derivations are variations of the general form of the StefanBoltzmann equation that relates clear sky incoming longwave radiation to atmospheric emissivity $\left(\varepsilon_{\text {clear }}\right)$, the StefanBoltzman constant $(\sigma)$, and air temperature $T_{\text {air }}(\mathrm{K})$.

$L_{\text {clear }}=\varepsilon_{\text {clear }} \sigma T_{\text {air }}^{4}$

Many of these parameterizations are site specific or do not incorporate a cloud cover component or account for longwave radiation emitted from the canopy (Hatfield et al., 1983; Alados-Alboledas et al., 1995). The presence and type of cloud cover affects how longwave radiation is absorbed and transmitted through the atmospheric air column, significantly affecting emissivity and subsequently the magnitude of incoming longwave radiation (Sicart et al., 2004; Lundquist et al., 2013). Incorporating a sky view factor $\left(S_{\mathrm{VF}}\right)$ into the longwave radiation calculations allowed us to partition the incoming longwave into atmospheric and forest canopy contributions.

Following Flerchinger et al. (2009) we performed a comparative analysis of various longwave radiation algorithms and measured net longwave radiation. Table S2 shows two clear sky algorithms and three cloud correction algorithms used in the comparison, totalling six combinations in all, with the "best-fit" algorithm determined by root mean squared error (RMSE). We measured longwave radiation using a Huskeflux NR1 net radiometer during spring 2013 for a 2-week period in a forested site within the MRB (Gleason et al., 2013) and for a 10-day period in an adjacent open area, excluding a 4-day period of rain. The NR1 measures four separate components of the surface radiation balance, separately measuring incoming and reflected solar radiation and both incoming and outgoing far infra-red radiation. The pyrogeometers have a built-in Pt100 temperature sensor for calculation of both the sky and surface temperature. Additionally, they are heated, with temperature compensation, to avoid moisture build-up on the thermopile sensors. The predicted incoming longwave radiation results of each method were then compared to the NR1 measured incoming longwave radiation using RMSE (Table S3). We found that the best approximation for incoming longwave energy was the clear sky algorithm of Dilley and O'Brien (1998) combined with the cloud adjustment of Crawford and Duchon (1999). The combined Crawford-Dilley method was therefore used in all longwave calculations going forward and is calculated as

$L \downarrow=\left(S_{\mathrm{VF}}\right) \varepsilon_{\text {adj }} \sigma T_{\text {air }}^{4}+\left(1-S_{\mathrm{VF}}\right) \varepsilon_{\text {snow }} \sigma\left(T_{\mathrm{C}}^{4}\right)$

where SVF is the sky view factor and represents the fraction of viewable sky from the perspective of the ground surface; $\varepsilon_{\text {adj }}$ is the adjusted atmospheric emissivity; and $T_{\mathrm{C}}$ is the temperature of the forest canopy $(\mathrm{K}) . T_{\mathrm{C}}$ is highly variable and typically not directly measured. The literature suggests a range of temperature of an increase of $4-30 \mathrm{~K}$ from 
measured air temperature (Derby and Gates, 1966; Pomeroy et al., 2003; Essery et al., 2008). We assumed canopy temperature to be equal to $T_{\text {air }}+4 \mathrm{~K}$ based on Boon (2009). Adjusted emissivity accounts for changes in atmospheric emissivity due to cloud cover and is found by adjusting the clear sky emissivity $\left(\varepsilon_{\text {clear }}\right)$ by some estimation of cloud cover. The Dilley and O'Brien (1998) clear sky algorithm is as

$$
\begin{aligned}
& L_{\text {clear }}=59.38+113.7 \cdot\left(\frac{T_{\text {air }}}{273.16}\right)^{6}+96.96 \sqrt{\frac{\omega}{25}}, \\
& \omega=\frac{465 \frac{e_{\mathrm{o}}}{100}}{T_{\text {air }}} .
\end{aligned}
$$

The Crawford and Duchon (1999) cloud correction adjusted algorithm requires $\varepsilon_{\text {clear }}$, which we computed from Eq. (8) and is in the following form:

$\varepsilon_{\text {adj }}=(1-r)+r \cdot \varepsilon_{\text {clear }}$,

where $r$ is the solar ratio, an approximation of cloud cover, and is equal to the ratio of measured incoming solar radiation and potential solar radiation (Lhomme et al., 2007).

\subsubsection{Turbulent heat flux}

The turbulent fluxes of latent and sensible heat are calculated using indirect methods. Latent heat exchange was calculated using the method found by Kustas et al. (1994):

$Q_{\mathrm{E}}=\left(\rho_{\mathrm{a}} 0.622 \frac{L_{\mathrm{v}}}{P_{\mathrm{a}}}\right) C_{\mathrm{e}} U_{\mathrm{Z}}\left(e_{\mathrm{a}}-e_{0}\right)$,

where $\rho_{\mathrm{a}}$ is the density of air $\left(\mathrm{kg} \mathrm{m}^{-3}\right), L_{\mathrm{V}}$ is the latent heat of vaporization or sublimation $\left(\mathrm{J} \mathrm{kg}^{-1}\right), P_{\mathrm{a}}$ is the total atmospheric pressure $(\mathrm{Pa}), C_{\mathrm{e}}$ is the bulk transfer coefficient for vapor exchange, $U(z)$ is the wind speed at height $Z(\mathrm{~m})$ above the snow surface $\left(\mathrm{ms}^{-1}\right), e_{\mathrm{a}}$ is the atmospheric vapor pressure at height $Z$ above the snow surface $(\mathrm{Pa})$, and $e_{0}$ is the vapor pressure at the snow surface $(\mathrm{Pa})$. This calculation favors the bulk aerodynamic approach adapted from Brutsaert (1982), as direct measurement is limited and successful implementation difficult in remote environments (Moore, 1983; Marks and Dozier, 1992; Marks et al., 1998). $C_{\text {en }}$ is the bulk transfer coefficient for vapor exchange under neutral stability and is calculated as

$C_{\text {en }}=k^{2}\left[\ln \left(\frac{Z}{Z_{0}}\right)\right]^{-2}$

where $k$ is von Karman's constant $0.4(-)$ and $Z$ is the height of the measurement above the snow surface (m) and was $3 \mathrm{~m}$ above the snow-free ground surface for the Low and Mid sites and $4.5 \mathrm{~m}$ for the High sites. Additionally, the surface roughness length $Z_{0}$ is a primary control on the bulk transfer coefficient, Eq. (12). The roughness length is affected by snow properties and is generally found to have values ranging from 0.001 to $0.005 \mathrm{~m}$ (Moore, 1983; Morris, 1989). This value represents the mean height of snow surface obstacles that impede air movement over the snow surface. In our analysis we used a median value, $0.003 \mathrm{~m}$, due to the variable nature of the seasonal snowpack.

The bulk aerodynamic approach is guided by stability conditions in the air above the snow surface. The stability of the air column is determined by application of the dimensionless bulk Richardson number $\left(R i_{\mathrm{B}}\right)$ which relates the density gradient to the velocity gradient, in this case the energy of buoyancy forces to the energy created by shear stress forces. $R i_{\mathrm{B}}$ is calculated as

$R i_{\mathrm{B}}=\frac{g Z\left(T_{\mathrm{air}}-T_{\text {snow }}\right)}{0.5\left(T_{\mathrm{air}}+T_{\text {snow }}\right) U(z)^{2}}$

where $g$ is the acceleration due to gravity, $9.81 \mathrm{~ms}^{-2}$. As Eq. (13) shows, the stability of the atmosphere is temperature dependent. Under stable conditions where the relatively warm air column settles the snow surface will cool and become dense, impeding turbulent mixing. Conversely, when the air column is relatively colder than the snow surface, free convection of the air column exists where the air warms and expands, causing increased mixing and unstable conditions. Positive values of $R i_{\mathrm{B}}$ indicate stable conditions, whereas negative values indicate instability. Corrections for atmospheric stability effects are inconsistent within the literature and therefore remain an area of continued study (Anderson, 1976; Oke, 1987; Kustas et al., 1994; Andreas, 2002). In this study we employ Eqs. (14a) and (14b) as the general stability correction equations (Oke, 1987):

Unstable: $\frac{C_{\mathrm{e}}}{C_{\mathrm{en}}}=\left(1-16 R i_{\mathrm{B}}\right)^{0.75}$;

Stable: $\frac{C_{\mathrm{e}}}{C_{\mathrm{en}}}=\left(1-5 R i_{\mathrm{B}}\right)^{2}$.

Sensible heat exchange, much like latent heat exchange, is controlled by temperature, wind speed, roughness length, and atmospheric stability conditions. Sensible heat flux was calculated as

$Q_{\mathrm{H}}=\rho_{\mathrm{a}} C_{\mathrm{p}} C_{\mathrm{h}} u_{\mathrm{a}}\left(T_{\text {air }}-T_{\text {snow }}\right)$

where $c_{\mathrm{p}}$ is the specific heat of dry air $\left(\mathrm{J} \mathrm{kg}^{-1} \mathrm{~K}^{-1}\right)$ and $C_{\mathrm{h}}$ is the bulk transfer coefficient for sensible heat. Here we assumed that $C_{\mathrm{e}}=C_{\mathrm{h}}$ and $C_{\mathrm{en}}=C_{\mathrm{hn}}$.

\section{Results}

\subsection{Snow surveys}

Values for 1 April SWE, as calculated from the NRCS SNOTEL stations, range from $9 \%$ (WY 2015) to $139 \%$ (WY 2012) of the 30-year median reference period (1981-2010). Snow surveys conducted at the Low and Mid elevation sites 

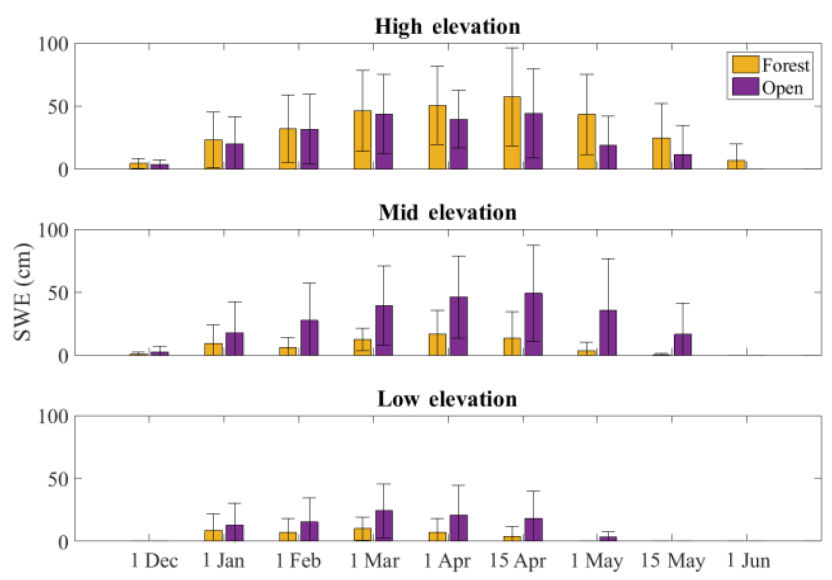

Figure 2. Average snow water equivalent (SWE) for the Open and Forest sites within the ForEST network, WY 2012-2014.

for WY 2012-14 show SWE at the Open site to be consistently greater and snow cover lasting longer into the spring than at the adjacent Forest site (Fig. 2). During the average snow year of WY 2013 (93\% of the 30-year median) the Low and Mid sites showed substantial differences between Open and Forest SWE throughout the accumulation and ablation seasons, whereas at the High sites SWE amounts were similar in Open and Forest. Conversely, snow lasted longer into the spring at the High Forest site relative to the High Open site. Because 1 April SWE may not accurately represent annual peak SWE at low and mid elevations within the PNW, we use the date of peak SWE in the following analysis. Therefore, peak SWE at the Low Open site was 209, 215,225 , and $242 \%$ of the Forest site peak SWE, respectively, for WY 2012-WY 2015. Peak SWE at the Mid Open site was 200, 280, 328, and $302 \%$ of the Forest site peak SWE, respectively, for WY 2012-WY 2015. However, SWE at the High Forest site is consistently higher than at the High Open site, 111, 103, 125, and $110 \%$ for WY 2012-WY 2015, respectively.

Excluding the historically low snowpack of WY 2015 (Sproles et al., 2017), the 3-year average snow depth ablation rates in the Forest sites at Low and Mid elevation were 1.3 and $1.2 \mathrm{~cm} \mathrm{~d}^{-1}$, while the Open sites were 4.1 and $3.1 \mathrm{~cm} \mathrm{~d}^{-1}$, respectively (Table 2). Melt rates at the High site were greater at both sites than their lower elevation counterparts, with a rate of $4.7 \mathrm{~cm} \mathrm{~d}^{-1}$ at the High Open site and a rate of $3.2 \mathrm{~cm} \mathrm{~d}^{-1}$ for the High Forest site. At Mid Open snow persistence exceeds that of the Mid Forest site by 1133 days. This is a similar finding to the low elevation sites, where snow lasted longer at Low Open by 4-26 days compared with the Low Forest site. Conversely, the High Forest site maintains snow longer into the spring by 15-29 days when compared to the High Open site.

\subsection{Forest characteristics and canopy interception efficiency}

Results show that $C_{\mathrm{IE}}$ in the Low and Mid Forest sites, for WY 2012-WY 2015, was 79 and $76 \%$ of the total event snowfall, whereas $C_{\mathrm{IE}}$ was $31 \%$ at the High Forest site (Table 2). $C_{\mathrm{IE}}$ showed no significant threshold behavior between event size and $C_{\mathrm{IE}}$, although there is an inverse relationship between duration and $C_{\mathrm{IE}}$ at the Low and Mid sites. Events that lasted for a single day had an average canopy interception efficiency of $87 \%$ with a reduction in average $C_{\mathrm{IE}}$ with increasing event length, from $73 \%$ for a 2-day event and $57 \%$ for a 3-day event to $51 \%$ for any event lasting longer than 4 days. Due to the low snow years of WY 2014 and WY 2015 the High site had only four events that lasted longer than 1 day, and therefore no relationship with event duration could be identified. Using event-based $C_{\mathrm{IE}}$ for all snowfall events we calculated how much snow was removed by the canopy at each elevation and compared that with each event snowfall amount (Fig. 3). The low elevation site has a high correlation between $C_{\mathrm{IE}}$ and event size for all qualifying events $\left(R^{2}=0.86\right)$ and an estimated overall snow removal efficiency of $58 \%$. The Mid elevation site has a lower correlation $\left(R^{2}=0.64\right)$ between $C_{\mathrm{IE}}$ and event size and an overall snow removal efficiency of $42 \%$. The linear relationship of the Low and Mid sites is similar to what Storck et al. (2002) found for a single Douglas fir (Pseudotsuga menziesii) over a 2-year study in Oregon, that $60 \%$ of event snowfall was intercepted by the canopy. This relationship does not hold at the high elevation site, with an overall snow removal efficiency of only $4 \%$. Further analysis using the Spearman rank correlation non-parametric measure shows similar results. The Spearman rank correlation coefficient $\left(r_{\mathrm{s}}\right)$ is 0.89 for both the low and mid elevation sites. This correlation does not persist at the high elevation sites $\left(r_{\mathrm{s}}=-0.05\right)$. We note an apparent threshold behavior where events less than $15 \mathrm{~cm}$ have a stronger linear relationship between event size and $C_{\mathrm{IE}}$ (Fig. 3) and the canopy was more effective at snow removal for events in that range compared with events greater than $15 \mathrm{~cm}$. For events $<15 \mathrm{~cm}$, canopy removal rates increase to $88 \%$ for the Low site and $89 \%$ for the Mid site, and interestingly, a weak correlation emerges, $R^{2}$ of 0.27 , with $50 \%$ removal for the High site.

\subsection{Energy balance}

To better understand the energy balance effect of forest canopies on snow accumulation and ablation, we calculated the mean daily energy balance components for the low and mid elevation sites for WY 2012-WY 2015 and for WY 2014 and WY 2015 for both high elevation sites (Fig. 4). Net radiation is the major component at all sites, while the turbulent fluxes and sensible and latent heat are only significant at the High Open site. Turbulent fluxes at all other sites are only episodically important and do not account for any significant 
Table 2. Summary snow statistics for WY 2012-WY 2014 - Oregon ForEST network.

\begin{tabular}{|c|c|c|c|c|c|c|c|c|c|}
\hline \multirow[b]{2}{*}{ Site } & \multicolumn{3}{|c|}{ WY2012 } & \multicolumn{3}{|c|}{ WY2013 } & \multicolumn{3}{|c|}{ WY2014 } \\
\hline & $\begin{array}{r}\text { Peak } \\
\text { SWE } \\
(\mathrm{cm})\end{array}$ & $\begin{array}{l}C_{\mathrm{IE}} \\
(\%)\end{array}$ & $\begin{array}{l}\text { Ablation } \\
\text { rate (depth } \\
\mathrm{cm} \mathrm{day}^{-1} \text { ) }\end{array}$ & $\begin{array}{r}\text { Peak } \\
\text { SWE } \\
(\mathrm{cm})\end{array}$ & $\begin{array}{l}C_{\mathrm{IE}} \\
(\%)\end{array}$ & $\begin{array}{l}\text { Ablation } \\
\text { rate (depth } \\
\left.\mathrm{cm} \mathrm{day}^{-1}\right)\end{array}$ & $\begin{array}{r}\text { Peak } \\
\text { SWE } \\
(\mathrm{cm})\end{array}$ & $\begin{array}{l}C_{\mathrm{IE}} \\
(\%)\end{array}$ & $\begin{array}{l}\text { Ablation } \\
\text { rate }(\text { depth } \\
\left.\mathrm{cm} \mathrm{day}^{-1}\right)\end{array}$ \\
\hline Low Forest & 23 & 70 & 1.6 & 24 & 75 & 1.9 & 8 & 92 & 0.4 \\
\hline Low Open & 48 & - & 4.0 & 51 & - & 4.3 & 18 & - & 1.3 \\
\hline Mid Forest & 45 & 70 & 1.0 & 26 & 75 & 1.3 & 12 & 83 & 1.1 \\
\hline Mid Open & 89 & - & 3.8 & 73 & - & 2.5 & 38 & - & 4.5 \\
\hline High Forest & 100 & - & 4.1 & 73 & - & 2.4 & 59 & 39 & 3.1 \\
\hline High Open & 90 & - & 5.4 & 71 & - & 2.9 & 42 & - & 5.9 \\
\hline
\end{tabular}

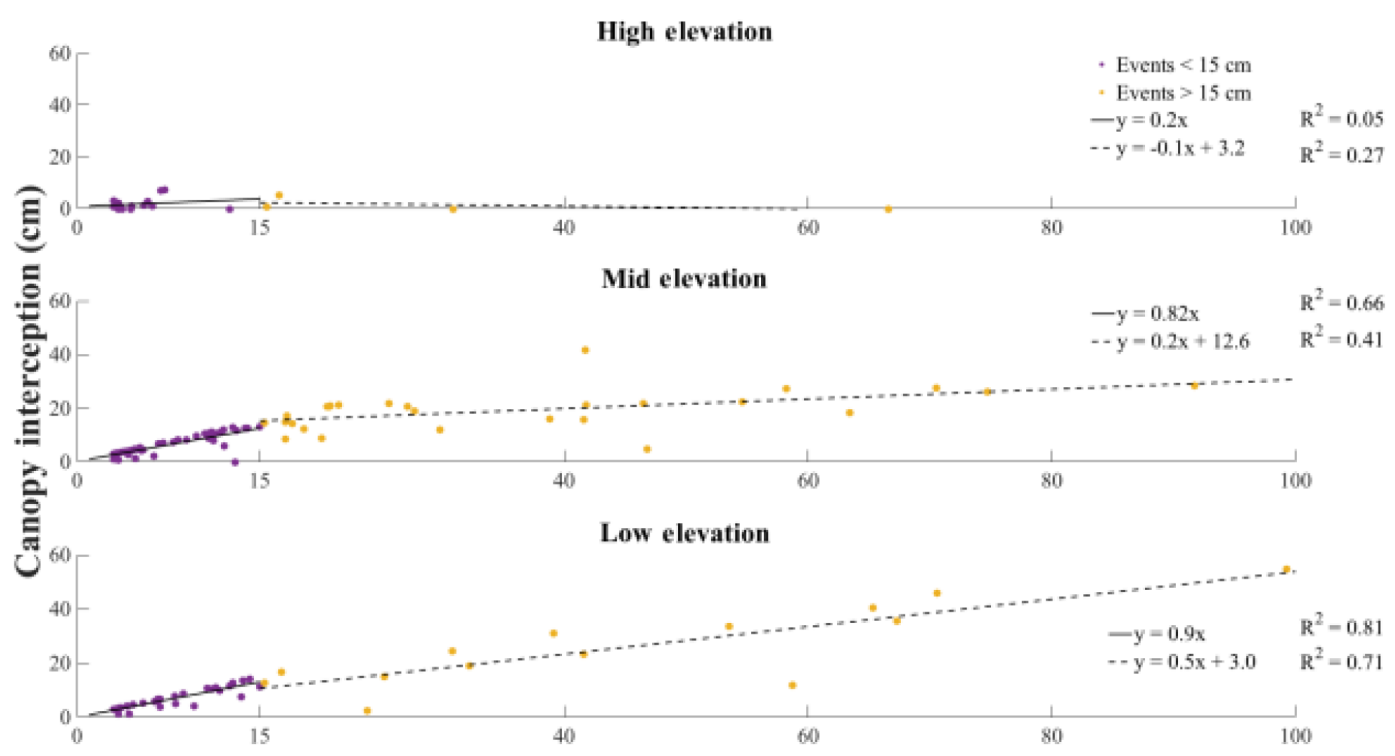

Figure 3. Canopy interception depth vs. event snowfall within the ForEST network.

amount of energy at the monthly or annual timescales. On an annual basis, shortwave radiation is the primary component of the energy balance at all Open sites, whereas longwave radiation dominates at all Forest sites. There is a strong dominance of shortwave (longwave) energy at the Low and Mid Open (Forest) sites, where it accounts for 89 and $71 \%$ (93 and $92 \%$ ) of the average annual net energy balance, respectively. At the High sites this trend persists, although the magnitudes change. Within the High Forest site, shortwave radiation accounts for the majority of energy received at the snow surface, but the annual total is reduced by $53 \%$, with net longwave radiation accounting for $47 \%$. Conversely, at the High Open site solar radiation accounts for $71 \%$ of the annual total, while longwave radiation is reduced to $7 \%$. The turbulent fluxes account for the remaining $22 \%$.

The stable atmospheric conditions at all sites, except the High Open site, reduce the turbulent fluxes to consistently insignificant values at the daily timescale, with only a few days over the course of the study period where these fluxes persist (Fig. 4). Not surprising then is the importance of the radiative fluxes for the net energy balance at all sites outside of the High Open site. Longwave radiation dominates at the Low and Mid Forest sites regardless of elevation or year (Figs. S1-S4 in the Supplement). Snowpack melt response to the increased longwave radiation in the forest from lasting events can be substantial. For example, at the Mid Forest site during an 8-day mid-January period, longwave radiation at the snow surface increased $71 \mathrm{~W} \mathrm{~m}^{-2}(225 \%$ increase), while snowmelt response was immediate and significant, attributed to a reduction of $32 \mathrm{~cm}(37 \%)$ in snowpack depth (Fig. 5). During the same period, longwave radiation increased $56 \mathrm{~W} \mathrm{~m}^{-2}$ (342\% increase) at the Mid Open site, while snowpack was reduced by $6 \mathrm{~cm}(5 \%)$. Throughout WY 2013 longwave radiation inputs are shown to have a strong inverse correlation with snowpack depth at the Mid Forest site (Fig. 5). This is not the case at the Mid Open site, where snowmelt is driven by shortwave radiation, with few accumulation season melt events at all, with snowpack set- 

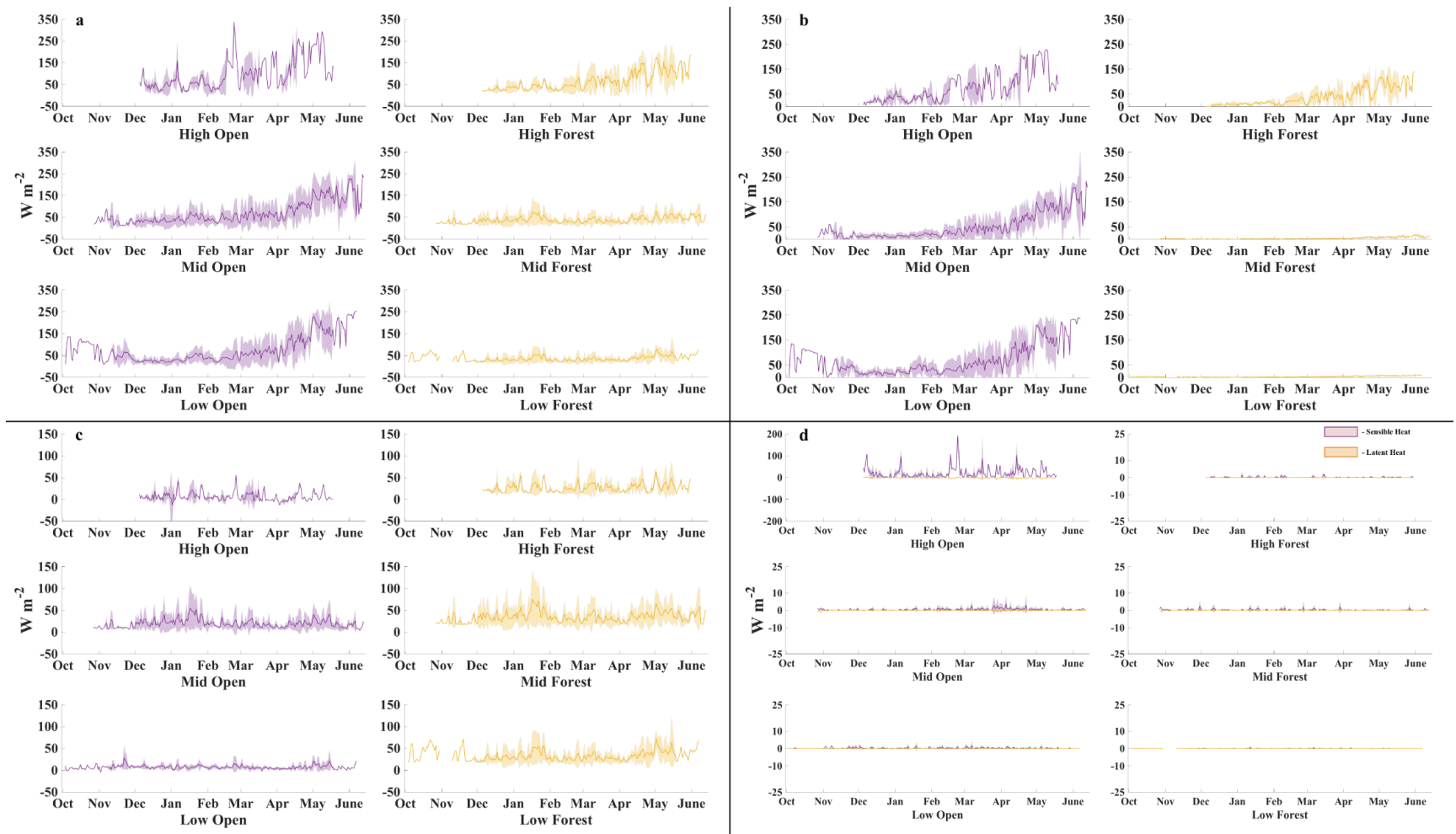

Figure 4. Calculated daily mean energy balance in $\mathrm{W} \mathrm{m}^{-2}$ (solid line) and the range of values (shaded area) for (a) net energy at the snow surface; (b) net solar radiation; (c) net longwave radiation; and (d) net turbulent energy at the snow surface for each site within the ForEST network, WY 2012-WY 2015.

tling attributed to the major snow reduction event in late December. A similar analysis at the High sites shows shortwave radiation driving the snowmelt response to mid-season melt events (Fig. S4). WY 2015 was a historically low year for the Pacific Northwest (Sproles et al., 2017); however, over a 4-day period in early January 2015 a large melt event occurred where the High Forest experienced a $37 \%$ reduction in snow depth and the High Open snow depth reduced by $50 \%$ (Fig. S4). Longwave radiation increased $94 \%$ at the Forest site, attributed to $71 \%$ of the total energy budget during the event. Conversely, the Open site longwave radiation increased $366 \%$, yet accounted for only $26 \%$ of the total net energy budget, with shortwave radiation at $49 \%$ and the net turbulent flux contributing the rest.

Air temperature is a first-order control in longwave radiation calculation and therefore it is expected that the lower and thus warmer sites will experience a larger percentage of net radiation in the form of longwave radiation. Average monthly air temperatures show that the High Forest site is 1.9 and $1.8^{\circ} \mathrm{C}$ cooler during the winter months (DJF) than the Low and Mid Forest sites, respectively (Fig. 6). Colder temperatures reduce the longwave radiation received at the snow surface during the winter months as longwave radiation is nonlinearly controlled by air temperature (Eq. 7). The reduced longwave input and lower forest density at the High
Forest site is reflected in the radiation budget where the net longwave energy component is $25 \%$ less than the net longwave energy at the Low and Mid Forest sites.

Wind speeds at all sites except at the High Open site are relatively weak and inconsistent, resulting in little turbulent mixing. Sustained (annual average) wind speeds at the High Open site are over 5 times greater than at any other site, with peak daily maxima more than 9 times greater (Fig. 7). At the High Open site high wind speeds occur frequently, while all other sites experience low wind speeds and little variability. Mean winter wind speed for the High Open site is $3.6 \mathrm{~m} \mathrm{~s}^{-1}$. Mean winter wind speeds for the Low and Mid Open sites are both $0.7 \mathrm{~m} \mathrm{~s}^{-1}$. The high wind speeds cause instability and subsequent turbulent mixing, resulting in much larger turbulent fluxes at the High Open site. Conversely, when wind speeds are low, minimal, if any, mixing occurs, and a decoupling of the snow surface and the atmosphere can persist. Calculation of the Richardson number (Eq. 13) determines the stability of the atmosphere, and where values are greater than 0.2 , this decoupling occurs. Although there is no consensus on what threshold this critical value should be, we use a threshold of 0.2 (Raleigh et al., 2013). Over the course of the study the $R i_{\mathrm{B}}$ value within each cover type at the Low and Mid elevation sites and the High Forest site exceeds the critical value for the majority of days. For example, in WY 

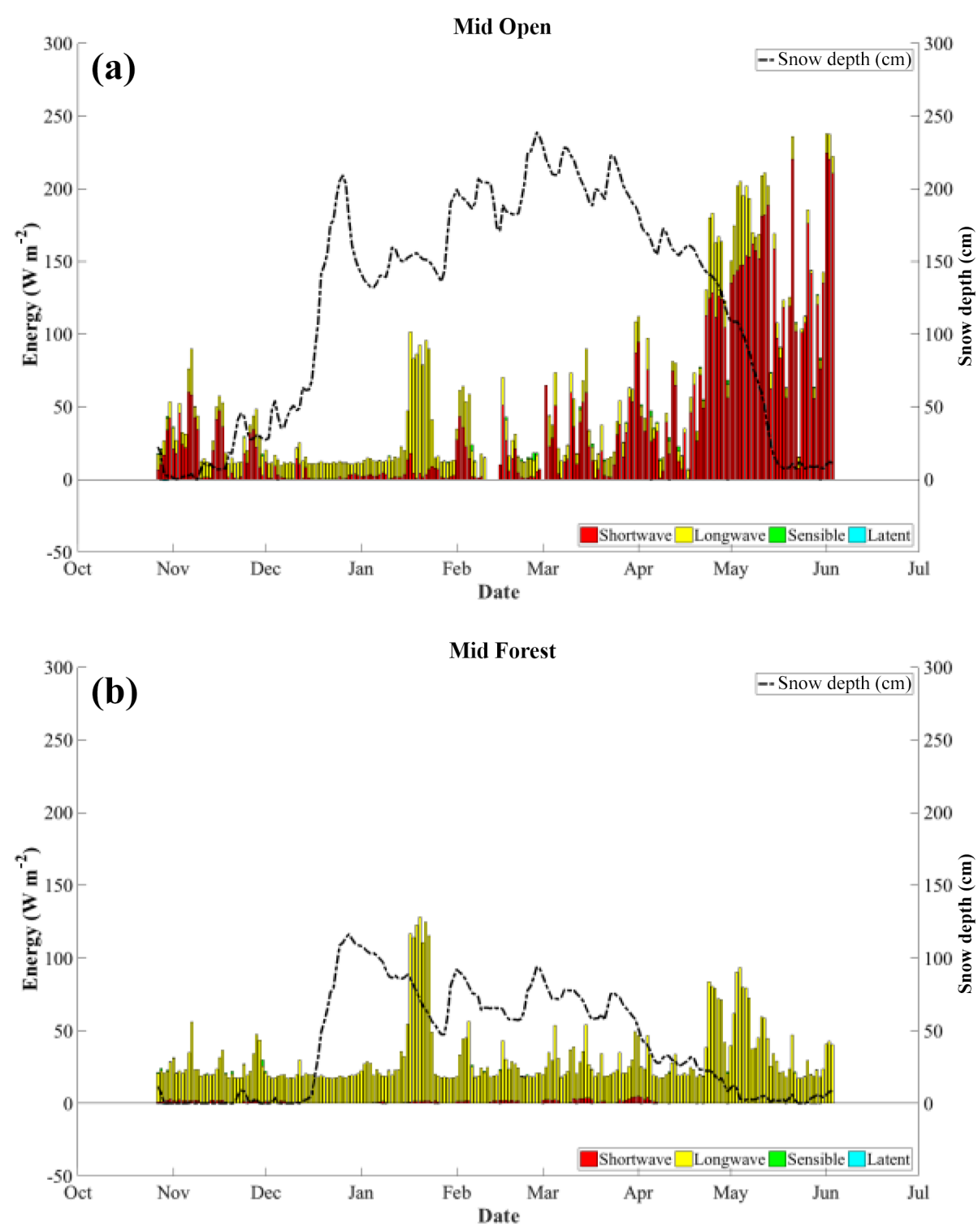

Figure 5. Calculated daily mean energy balance component magnitudes (bars) and the daily measured snow depth (dashed line) for Mid Open (a) and Mid Forest (b) during WY 2013.

2014 the critical value was exceeded $60 \%$ of the time at both the Low sites, 76 and $71 \%$ at the Mid Open and Mid Forest sites, $82 \%$ of the time at the High Forest site, and only $10 \%$ of the time at the High Open site.

Forest structure at the Low and Mid Forest sites is typified by average crown diameters of 9.4 and $6.7 \mathrm{~m}$ and average LAIs of 2.4 and 2.7, respectively. At the High Forest site average crown diameter and LAI were measured as 2.8 and $1.1 \mathrm{~m}$, respectively. A multi-layered and randomly distributed forest canopy greatly impacts the amount of solar radiation reaching the forest floor through beam attenuation (Campbell, 1986). Forest canopies provide solar shading as the spring progresses and solar angle increases, intensifying the incoming solar radiation. At the Low and Mid Forest sites where canopy interception is high, the impact of solar shading becomes less pronounced and snowpack SWE is not preserved late into the spring. With snowfall magnitude essentially the same at the mid and high elevations, we see that the snowpack lasts much longer into the spring at the High Forest site when forest shading has a meaningful effect on reducing solar inputs into the snowpack.

\section{Discussion}

In maritime snow zones where winter precipitation is often a mix of rain and snow, multiple mechanisms align to contradict the conventional wisdom that snow is retained longer in forests than in open areas (Link and Marks, 1999; Jost 

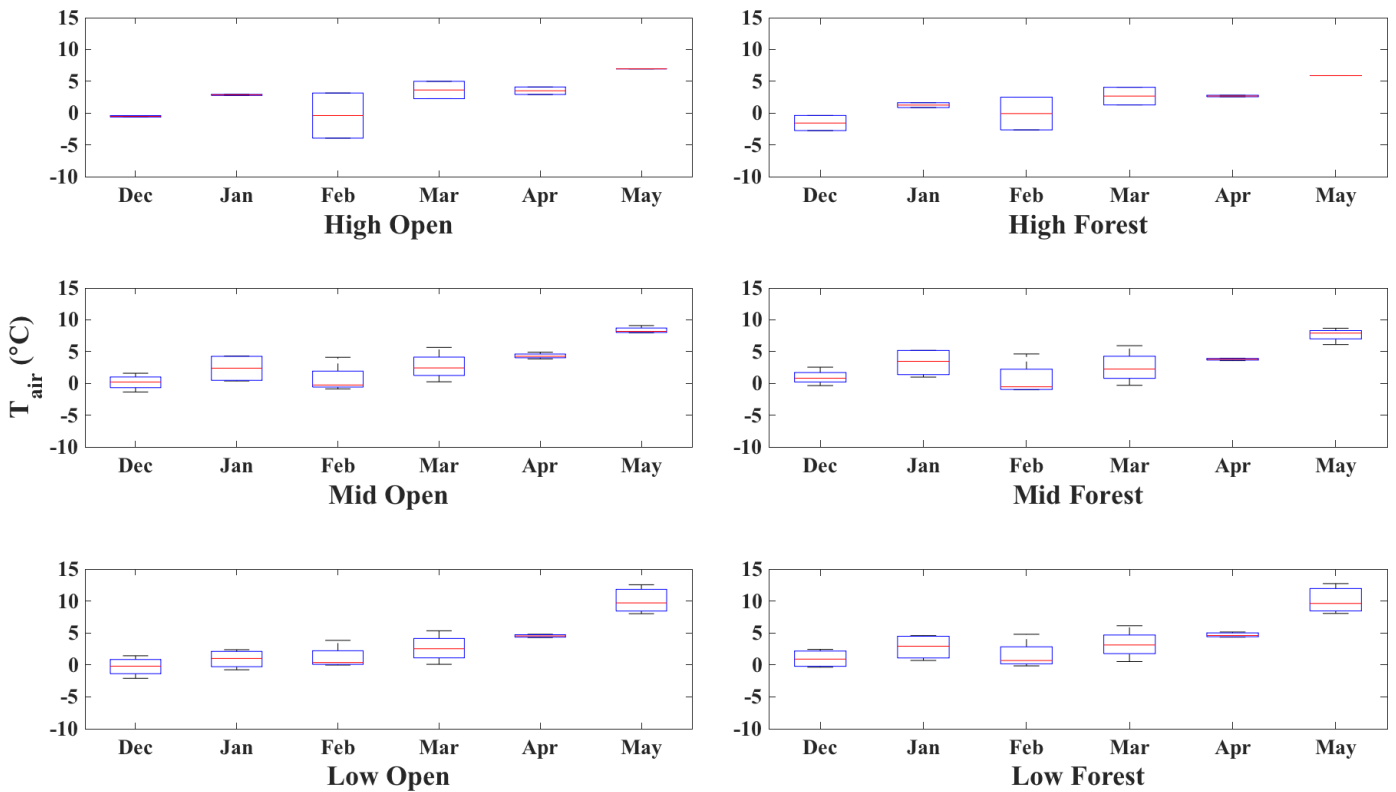

Figure 6. Boxplot of average monthly air temperature for each site within the ForEST network, WY 2012-WY 2015.
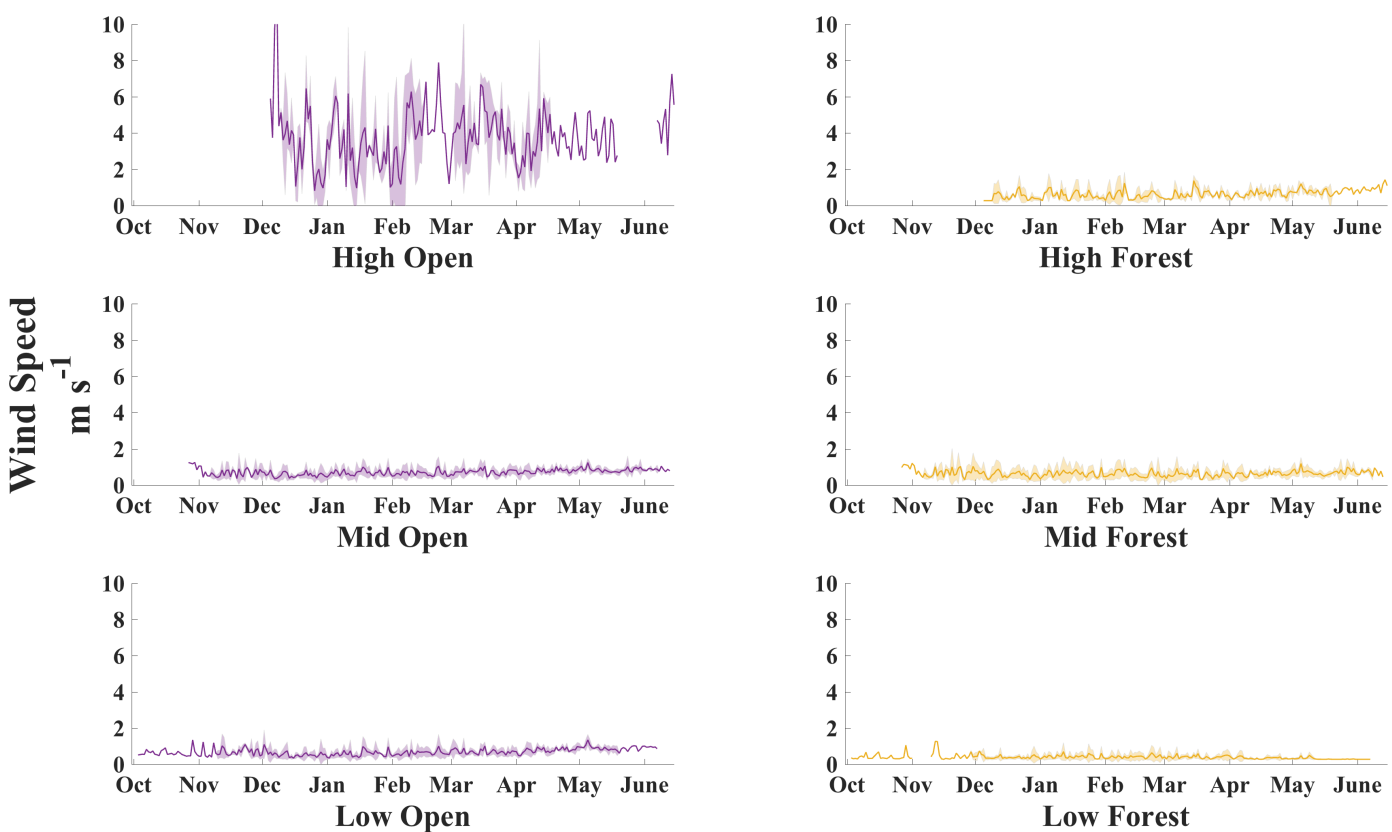

Figure 7. Daily average wind speed (heavy solid line) and the range of wind speeds (shaded area) for each site within the ForEST network, WY 2012-WY 2015.

et al., 2007; Musselman et al., 2008). Multi-layered forest cover and a relatively warm forest increase canopy interception efficiency, resulting in significant reductions in subcanopy snow accumulation (Storck et al., 2002). While no significant relationship existed between daily air temperature and $C_{\mathrm{IE}}$ within our study $(p>0.005)$, a threshold behavior appears to exist where events under $15 \mathrm{~cm}$ seem to be highly correlated with $C_{\mathrm{IE}}$. This suggests a nonlinear relationship for event-scale canopy interception in dense, relatively warm forests. The slopes of trend lines in Fig. 3 show that the dense forests at these Low and Mid Forest sites remove a considerable amount of snow from each event, significantly reducing sub-canopy accumulation. The high snow removal capacities of these forests suggest canopy density is a first-order process in snow accumulation. 
While few studies in maritime forested environments on the energy balance exist, there is evidence of longwave radiation as the dominating term during rain on snow (ROS) events within forests (Berris and Harr, 1987; Mazurkiewicz et al., 2008; Garvelmann et al., 2014). Berris and Harr (1987) showed that longwave radiation accounted for $38-88 \%$ of all ROS event snowmelt. Garvelmann et al. (2014) found that in two ROS events longwave radiation accounted for 55.1 and $38.8 \%$ of the net energy balance, although this may be biased low due to the inability to accurately capture tree trunk temperature. Although Mazurkiewicz et al. (2008) did not differentiate between radiation terms, they found that net radiation was the largest contributor to melt. The highly nonlinear relationship between air temperature and incoming longwave radiation formulation is apparent in the net radiation budget analysis. Infrequent cloud-free days and the warm, dense forests of the study area combine to emit a significant amount of longwave radiation to the snow surface (Berris and Harr, 1987; Sicart et al., 2004; Garvelmann et al., 2014). This leads to a positive net snow surface energy balance and midwinter melt events, most pronounced at the warmer lower elevation sites. With prolonged exposure to longwave radiation emitted by the canopy and the high efficiency of warm forest canopy interception capabilities, low elevation maritime subcanopy snowpacks are relatively thin and do not persist long enough into the spring season to benefit from forest shading. This creates a radiative paradox where the longwave radiation emitted by dense and relatively warm forest cover exceeds the resulting reduction in shortwave radiation due to forest shading (Sicart et al., 2004; Lawler and Link, 2011; Lundquist et al., 2013). The higher elevation sites experience colder air temperatures, higher wind speeds, and lower forest density, which combine to decrease $C_{\mathrm{IE}}$ and the impact of longwave radiation on mid-winter melt events. Furthermore, relatively low ablation rates for the Low and Mid Forest sites suggest that forests do provide some radiative shading during the melt season. However, the benefit of solar shading can only be realized if a sufficient snow cover is present. Otherwise, the effects of reduced solar inputs become secondary and it is the accumulation rate, or more precisely, the efficiency of the canopy interception, that is the principle control on the date of snow disappearance.

Here, we considered that wind may have an impact on canopy snow unloading and subsequent increases in subcanopy snow accumulation. While a seasonal mean presents a general view of the wind environment at each Open site, it masks the variability of wind gusts that can drive snow redistribution. Using the 10 min mean wind speeds better depicts the wind characteristics that can affect wind redistribution of snow. Pomeroy and Gray (1990) suggest that for wet snow a snow transport wind threshold of $7-10 \mathrm{~m} \mathrm{~s}^{-1}$ measured at $10 \mathrm{~m}$ above the ground surface must be exceeded before any redistribution can occur. Using this threshold, the High Open site measured wind speeds met or exceeded the lower threshold $9.9 \%$ of the entire record and $14.4 \%$ if we translate measured wind speed to $Z=10 \mathrm{~m}$ using a simple wind profile power law. This represents a substantial amount of the snow season and enough to suggest that wind redistribution is possible. More likely is the wind effect on deposition of snowfall. The influence of the forest on the reduction of wind speeds at the high elevation sites can lead to preferential deposition within the forest as the wind speeds attenuate. Once snow is deposited onto the ground the wet maritime snow makes it difficult to be redistributed as a result of saltation and suspension. However, the Open site experiences high enough sustained wind speeds to effectively redistribute and transport wet maritime snow from the High Open site into the adjacent High Forest site. Although the magnitude of this redistribution of snow from Open to Forest is unknown, it is reasonable to assume that it is not insignificant considering the sustained high winds of the High Open environment.

The effects of elevation position within a watershed and forest structure on snow persistence can have serious implications within a warming climate. Sproles et al. (2013) documented a $150 \mathrm{~m}$ increase in the elevation of the snow line for every $1{ }^{\circ} \mathrm{C}$ temperature increase and showed that projected temperature increases of about $2{ }^{\circ} \mathrm{C}$ would shift precipitation at $1500 \mathrm{~m}$ from snowfall to a rain-snow mix. If that were to occur, then forests at that elevation, e.g., the High Forest site, that now help maintain late spring snowpacks would likely behave more like the lower elevation forests in which snowmelt occurs earlier than in the Open areas, effectively offsetting any solar shading gains that the forest can provide in the present. Peak SWE and spring runoff would be reduced at these higher elevations. These high elevation forests could lose their dry season "moisture subsidy" and suffer increased moisture stress, with wide-ranging implications for forest and water resource managers.

\section{Conclusions}

This paper highlights the complex snow-forest process relationships and suggests that forest cover is a principal control on snow persistence due to reduced accumulation from canopy interception and earlier/faster melt due to increased longwave radiation. High density, relatively warm forests have high canopy interception efficiency that controls subcanopy snowpack evolution and mediates the amount of springtime solar shading of the snowpack. The cooler and less dense High Forest site has a reduced interception efficiency and acts as a snow deposition reservoir for the nearby windy High Open site. Net radiation drives the snow surface energy balance, with the partitioning between longwave and shortwave a function of forest complexity. Our study demonstrates the sensitivity of Pacific Northwest snowpack development to temperature and forest cover. Nolin and Daly (2006) demonstrated that much of the Oregon Cascade snowpack is at risk, the ForEST network included, by looking 
at temperature only. Similarly, Sproles et al., 2013 showed that the lower boundary of the snow zone has little resilience to a warming world. Our paper demonstrates that understanding the snowpack energy budget is key to understanding how forests influence snow accumulation and melt. By quantifying the mechanisms of how vegetation affects subcanopy snowpack energy balance, the results of this study provide the basis for understanding the sensitivity of maritime snowpacks to a changing climate. As climate continues to warm, we anticipate reduced snow accumulation at elevations where snowfall shifts to a rain-snow mix, and amplified sub-canopy melt rates due to longwave radiative heating in warmer forests, thereby reducing overall forest snow retention. However, higher elevation colder sites with a less dense forest can mitigate that to some extent by retaining the snowpack longer through lower relative forest longwave emission and lower canopy interception. A key finding within this study is that throughout the study duration, one that saw high inter-annual snowfall variability, a definitive pattern emerged within the energy budget and snowpack dynamics across the network. The energy budget format that we present here goes beyond the temperature only approach while getting at the causal effects and mechanisms of the challenge of vegetation-snowpack interactions for a warming climate.

While these results are focused on the Oregon Cascades, they have broader implications for other relatively warm forested snow environments with elevation gradients, such as parts of the California Sierra Nevada, the Japanese and European Alps, and the Pyrenees (Lundquist et al., 2013). These results will aid in improving parameterizations of snow-forest interactions in physically based snow hydrology models and land surface models. Additionally, as climate change alters regional snow deposition patterns across the western US, our findings are applicable to land and water managers, seeking to improve forest snowpack retention, enhance forest health, and improve streamflow forecasting. This study demonstrates the value of plot-scale snow-forest process studies for improving our understanding of the forest effects on snowpack evolution. Future work will focus on a multi-scale approach that incorporates remote sensing and snow hydrology modeling to identify forest structure metrics that are well suited to accurately modeling snow-forest interactions. Such an approach will allow the snow community to quantify the improvement of snow-forest interactions across spatial scales and enhance model prediction for landscape and regional applications.

Data availability. The data used in this study are freely available online from the Oregon State University ScholarsArchive: https://ir. library.oregonstate.edu/xmlui/handle/1957/59984 (Roth and Nolin, 2016).

\section{The Supplement related to this article is available online at https://doi.org/10.5194/hess-21-5427-2017- supplement.}

Competing interests. The authors declare that they have no conflict of interest.

Acknowledgements. This research was made possible by funding provided by the National Science Foundation (EAR 1039192) and from a NASA Earth Science Student Fellowship (16-EARTH16F0426). We thank Willamette National Forest for providing access permits for the ForEST network. Additional material support was provided by the Western Ecology Division office of the Environmental Protection Agency, with special thanks to Ron Waschmann. We thank the many student interns who assisted in snow surveys and site maintenance.

Edited by: Jan Seibert

Reviewed by: three anonymous referees

\section{References}

Alados-Alboledas, L., Vida, J., and Olmo, F. J.: The estimation of thermal atmospheric radiation under cloudy skies, Int. J. Climate, $15,107-116,1995$.

Allen, C. D., Macalady, A. K., Chenchouni, H., Bachelet, D., McDowell, N., Vennetier, M., Kitzberger, T., Rigling, A., Breshears, D. D., Hogg, E. H., Gonzalez, P., Fensham, R., Zhang, Z., Castro, J., Demidova, N., Lim, J. H., Allard G., Running, S. W., Semerci, A., and Cobb, N.: A global overview of drought and heat-induced tree mortality reveals emerging climate change risks for forests, Forest Ecol. Manag., 259, 660-684, 2010.

Anderson, E. A.: A point energy balance and mass balance model of snow cover, Silver Spring, Md., US DOC NOAA, Tech Rpt., NWS 19, 1976.

Andreadis, K. M., Storck, P., and Lettenmaier, D. P.: Modeling snow accumulation and ablation processes in forested environments, Water Resour. Res., 45, 1-13, https://doi.org/10.1029/2008WR007042, 2009.

Andreas, E. L.: A new method of measuring the snowsurface temperature, Cold Reg. Sci. Technol., 12, 139-156, https://doi.org/10.1016/0165-232X(86)90029-7, 1986.

Andreas, E. L.: Parameterizing scalar transfer over snow and ice: a review, J. Hydrometeorol., $3, \quad 417-432, \quad$ https://doi.org/10.1175/15257541(2002)003<0417:PSTOSA>2.0.CO;2, 2002.

Berris, S. N. and Harr, R. D.: Comparative snow accumulation and melt during rainfall in forested and clear-cut plots in the western Cascades of Oregon, Water Resour. Res., 23, 135-142, https://doi.org/10.1029/WR023i001p00135, 1987.

Bewley, D., Alila, Y., and Varhola, A.: Variability of snow water equivalent and snow energetics across a large catchment subject to Mountain Pine Beetle infestation and rapid salvage logging, J. Hydrol., 388, 464-479, 2010. 
Boon, S.: Snow ablation energy balance in a dead forest stand, Hydrol. Process., 23, 2600-2610, https://doi.org/10.1002/hyp.7246, 2009.

Brooks, J. R., Wigington, P. J., Phillips, D. L., Comeleo, R., and Coulombe, R.: Willamette River Basin surface water isoscape $\left(\delta^{18} \mathrm{O}\right.$ and $\left.\delta^{2} \mathrm{H}\right)$ : temporal changes of source water within the river, Ecosphere, 3, 39, https://doi.org/10.1890/es11-00338.1, 2012.

Brutsaert, W.: On a derivable formula for long-wave radiation from clear skies, Water Resour. Res., 11, 742-744, 1975.

Brutsaert, W.: Evaporating Into the Atmosphere: Theory, History, and Applications, D. Reidel Publ. Co., Dordrecht, 1982.

Campbell, G. S.: Extinction coefficients for radiation in plant canopies calculated using an ellipsoidal inclination angle distribution, Agr. Forest Meteorol., 36, 317-321, 1986.

Choat, B., Jansen, S., Brodribb, T. J., Cochard, H., Delzon, S., Bhaskar, R., Bucci, S. J., Field, T. S., Gleason, S. M., Hacke, U. G., Jacobsen, A. L., Lens, F., Maherali, H., MartinezVilalta, J., Mayr, S., Mencuccini, M., Mitchell, P. J., Nardini, A., Pittermann, J., Pratt, R. B., Sperry, J. S., Westoby, M., Wright, I. J., and Zanne, A. E.: Global convergence in the vulnerability of forests to drought, Nature, 491, 752-755, 2012.

Crawford, T. M. and Duchon, C. E.: An improved parameterization for estimating effective atmospheric emissivity for use in calculating daytime downwelling longwave radiation, J. Appl. Meteorol., 48, 474-480, 1999.

Dai, A.: Increasing drought under global warming in observations and models, Nat. Clim. Change, 3, 52-58, https://doi.org/10.1038/nclimate1633, 2013.

Derby, R. W. and Gates, D. M.: The temperature of tree trunks calculated and observed, Am. J. Bot., 53, 580-587, 1966.

Dickerson-Lange, S. E., Lutz, J. A., Martin, K. A., Raleigh, M. S., Gersonde, R., and Lundquist, J. D: Evaluating observational methods to quantify snow duration under diverse forest canopies, Water Resour. Res., 15, 1203-1224, https://doi.org/10.1002/2014WR015744, 2015.

Dilley, A. C. and O'Brien, D. M.: Estimating downward clear sky long-wave irradiance at the surface from screen temperature and precipitable water, Q. J. Roy. Meteor. Soc., 124, 1391-1401, 1998.

Elder, K., Dozier, J., and Michaelsen, J.: Snow accumulation and distribution in an alpine watershed, Water Resour. Res., 27, 1541552, 1991.

Elder, K., Rosenthal, W., and Davis, R. E.: Estimating the spatial distribution of snow water equivalence in a montane watershed, Hydrol. Process., 12, 1793-1808, 1998.

Ellis, C. R., Pomeroy, J. W., and Link, T. E.: Modeling increases in snowmelt yield and desynchronization resulting from forest gap-thinning treatments in a northern mountain headwater basin, Water Resour. Res., 49, 936-949, https://doi.org/10.1002/wrcr.20089, 2013.

Elzinga, C. L., Salzer, D. W., and Willoughby, J. W.: Measuring and Monitoring Plant Populations, USDI Bureau of Land Management Technical Reference 1730-1, National Business Center, Denver, CO, 1998.

Essery, R., Pomeroy, J. W., Ellis, C., and Link, T. E.: Modeling longwave radiation to snow beneath forest canopies using hemispherical photography or linear regression, Hydrol. Process., 22, 2788-2800, https://doi.org/10.1002/hyp.6930, 2008.
Flerchinger, G. N., Xaio, W., Marks, D., Sauer, T. J., and $\mathrm{Yu}$, Q.: Comparison of algorithms for incoming atmospheric long-wave radiation, Water Resour. Res., 45, W03423, https://doi.org/10.1029/2008WR007394, 2009.

Frazer, G., Canham, C., and Lertzman, K.: Gap Light Analyzer (GLA): Imaging Software to Extract Canopy Structure and Gap Light Transmission Indices from True-Colour Fisheye Photographs: User's Manual and Program Documentation, Simon Fraser University, Burnaby, BC, https://doi.org/10.1016/S01681923(01)00274-X, 1999.

Friesen, J., J. Lundquist, J., and Van Stan, J. T.: Evolution of forest precipitation water storage measurement methods, Hydrol. Process., 29, 2504-2520, https://doi.org/10.1002/hyp.10376, 2014.

Gary, H. L.: Snow accumulation and snowmelt as influenced by a small clearing in a lodgepole pine forest, Water Resour. Res., 10, 348-353, https://doi.org/10.1029/WR010i002p00348, 1974.

Garvelmann, J., Pohl, S., and Weiler, M.: Variability of observed energy fluxes during rain-on-snow and clear sky snowmelt in a midlatitude mountain environment, J. Hydrometeorol., 15, 1220 1236, 2014.

Geddes, C. A., Brown, D. G., and Farge, D. B.: Topography and Vegetation as Predictors of Snow Water Equivalent Across the Alpine Treeline Ecotone at Lee Ridge, Glacier National Park, Montana, USA, Arct. Antarct. Alp. Res., 37, 197-205, 2005.

Gleason, K. E. and Nolin, A. W.: Charred forests accelerate snow albedo decay: parameterizing the post-fire radiative forcing on snow for three years following fire, Hydrol. Process., 197-205, https://doi.org/10.1002/hyp.10897, 2016.

Gleason, K. E., Nolin, A. W., and Roth, T. R.: Charred forests increase snowmelt: effects of burned woody debris and incoming solar radiation on snow ablation, Geophys. Res. Lett., 40, 46544661, https://doi.org/10.1002/grl.50896, 2013.

Gleason, K. E., Nolin, A. W., and Roth, T. R.: Developing a representative snow-monitoring network in a forested mountain watershed, Hydrol. Earth Syst. Sci., 21, 1137-1147, https://doi.org/10.5194/hess-21-1137-2017, 2017.

Gray, D. M.: Snow accumulation and distribution, in: Proceedings, Modelling of Snow Cover Runoff, edited by: Colbeck, S. C., and Ray, M., US Army Cold Regions Research and Engineering Laboratory, Hanover, NH, 3-33, 1979.

Hardy, J. P., Marks, D., Link, T., and Koenig, G.: Variability of the below canopy thermal structure over snow, Eos Trans. AGU, Fall Meet Suppl., 85(47): F448, 2004.

Harpold, A. A., Biederman, J. A., Condon, K., Merino, M., Korgaonkar, Y., Nan, T., Sloat, L. L., Ross, M., and Brooks, P. D.: Changes in snow accumulation and ablation following the Las Conchas Forest Fire, New Mexico, USA, Ecohydrology, 7, 440 452, https://doi.org/10.1002/eco.1363, 2013.

Harpold, A. A., Molotch, N. P., Musselman, K. N., Bales, R. C., Kirchner, P. B., Litvak, M., and Brooks, P. D.: Soil moisture response to snowmelt timing in mixed-conifer subalpine forests, Hydrol. Process., 29, 2782-2798, https://doi.org/10.1002/hyp.10400, 2015.

Hatfield, J. L., Reginato, R. J., and Idso, S. B.: Comparison of longwave radiation calculation methods over the United States, Water Resour. Res., 19, 285-288, 1983.

Hedstrom, N. R. and Pomeroy, J. W.: Measurements and modeling of snow interception in the boreal forest, Hydrol. Process., 12, 1611-1625, https://doi.org/10.1002/(SICI)1099- 
1085(199808/09)12:10/11<1611::AID-HYP684>3.0.CO;2-4, 1998.

Homer, C., Dewitz, J., Fry, J., Coan, M., Hossain, N., Larson, C., Herold, N., McKerrow, A., VanDriel, J. N., and Wickham, J.: Completion of the 2001 National Land Cover Database for the Conterminous United States, Photogramm. Eng. Rem. S., 73, 337-341, 2007

Inoue, A., Yamamoto, K., Mizoue, N., and Kawahara, Y.: Calibrating view angle and lens distortion of the Nikon fish-eye converter FC-E8, J. Forest Res., 9, 17, https://doi.org/10.1007/s10310-0030073-8, 2004

Jefferson, A., Nolin, A., Lewis, S., and Tague, C.: Hydrogeologic controls on streamflow sensitivity to climate variation, Hydrol. Process., 22, 4371-4385, https://doi.org/10.1002/hyp.7041, 2008.

Jost, G., Weiler, M., Gluns, D. R., and Alila, Y.: The influence of forest and topography on snow accumulation and melt at the watershed-scale, J. Hydrol., 347, 101-115, https://doi.org/10.1016/j.jhydrol.2007.09.006, 2007.

Kustas, W. P., Rango, A., and Uijlenhoet, R.: A simple energy budget algorithm for the snowmelt runoff model, Water Resour. Res., 30, 1515-1527, 1994.

Lawler, R. R. and Link, T. E.: Quantification of incoming allwave radiation in discontinuous forest canopies with application to snowmelt prediction, Hydrol. Process., 25, 3322-3331, https://doi.org/10.1002/hyp.8150, 2011.

Lhomme, J. P., Vacher, J. J., and Rocheteau, A.: Estimating downward long-wave radiation on the Andean Altiplano, Agr. Forest Meteorol., 145, 139-1482, 2007.

Link, T. E. and Marks, D.: Distributed simulation of snowcover mass- and energy-balance in the boreal forest, Hydrol. Process., 13, 2439-2452, 1999.

Liston, G. E. and Sturm, M.: A snow-transport model for complex terrain, J. Glaciol., 44, 498-516, 1998.

López-Moreno, J. I. and Latron, J.: Influence of canopy density on snow distribution in a temperate mountain range, Hydrol. Process., 22, 117-126, 2008.

López-Moreno, J. I. and Stähli, M.: Statistical analysis of the snow cover variability in a subalpine watershed: assessing the role of topography and forest interactions, J. Hydrol., 348, 379-394, 2008.

Lundquist, J. E., Dickerson-Lange, S. E., Lutz, J. A., and Cristea, N. C.: Lower forest density enhances snow retention in regions with warmer winters: a global framework developed from plot-scale observations and modeling, Water Resour. Res., 49, 6356-6370, https://doi.org/10.1002/wrcr.20504, 2013.

Lyon, S. W., Troch, P. A., Broxton, P. D., Molotch, N. P., and Brooks, P. D.: Monitoring the timing of snowmelt and the initiation of streamflow using a distributed network of temperature/light sensors, Ecohydrology, 1, 215-224, https://doi.org/10.1002/eco.18, 2008.

Marks, D. and Dozier, J.: Climate and energy exchange at the snow surface in the alpine region of the Sierra Nevada, 2, Snow cover energy balance, Water Resour. Res., 28, 3043-3054, https://doi.org/10.1029/92WR01483, 1992.

Marks, D., Kimball, J., Tingey, D., and Link, T. E.: The sensitivity of snowmelt processes to climate conditions and forest cover during rain-on-snow: a case study of the 1996 Pacific Northwest flood, Hydrol. Process., 12, 1569-1587,
https://doi.org/10.1002/(SICI)1099-1085(199808/09)12:10/11, 1998.

Martin, K. A., Van Stan, J. T., Dickerson-Lange, S. E., Lutz, J. A., Berman, J. W., Gersonde, R., and Lundquist, J. D.: Development and testing of a snow interceptometer to quantify canopy water storage and interception processes in the rain/snow transition zone of the North Cascades, Washington, USA, Water Resour. Res., 49, 3243-3256, https://doi.org/10.1002/wrcr.20271, 2013.

Mazurkiewicz, A. B., Callery, D. G., and McDonnell, J. J.: Assessing the controls of the snow energy balance and water available for runoff in a rain-on-snow environment, J. Hydrol., 354, 1-14, https://doi.org/10.1016/j.jhydrol.2007.12.027, 2008.

McCabe, G. J. and Clark, M. P.: Trends and variability in snowmelt runoff in the western United States, J. Hydrometeorol., 6, 476482, 2005.

Melloh, R. A., Hardy, J. P., Bailey, R. N., and Hall, T.: An efficient snow albedo model for the open and subcanopy, Hydrol. Process., 16, 3571-3584, https://doi.org/10.1002/hyp.1229, 2002.

Miller, J. D., Safford, H. D., Crimmins, M. A., and Thode, A. E.: Quantitative evidence for increasing forest fire severity in the Sierra Nevada and southern Cascade Mountains, California and Nevada, USA, Ecosystems, 12, 16-32, 2009.

Moeser, D., Stähli, M., and Jonas, T.: Improved snow interception modeling using canopy parameters derived from airborne LiDAR data, Water Resour. Res., 51, 5041-5059, https://doi.org/10.1002/2014WR016724, 2015.

Molotch, N. P. and Bales, R. C.: SNOTEL representativeness in the Rio Grande headwaters on the basis of physiographics and remotely sensed snow cover persistence, Hydrol. Process., 20, 723-739, 2006.

Moore, R. D.: On the use of bulk aerodynamic formulae over melting snow, Nord. Hydrol., 14, 193-206, 1983.

Moritz, M. A., Parisien, M. A., Batllori, E., Krawchuk, M. A., Van Dorn, J., Ganz, D. J., and Hayhoe, K.: Climate change and disruptions to global fire activity, Ecosphere, 3, 49, https://doi.org/10.1890/ES11-00345.1, 2012.

Morris, E.: Turbulent transfer over snow and ice, J. Hydrol., 105, 205-223, 1989.

Mote, P. W.: Climate-driven variability and trends in mountain snowpack in western North America, J. Climate, 19, 6209-6220, 2006.

Musselman, K., Molotch, N. P., and Brooks, P. D.: Effects of vegetation on snow accumulation and ablation in a midlatitude sub-alpine forest, Hydrol. Process., 22, 2767-2776, https://doi.org/10.1002/hyp.7050, 2008.

Musselman, K., Clark, M. P., Liu, C., Ikeda, K., and Rasmussen, R.: Slower snowmelt in a warmer world, Nat. Clim. Change, 7, 214 220, https://doi.org/10.1038/NCLIMATE3225, 2017.

Nolin, A. W. and Daly, C.: Mapping "at risk" snow in the Pacific Northwest, J. Hydrometeorol., 7, 1164-1172, https://doi.org/10.1175/JHM543.1, 2006.

O’Halloran, T. L., Law, B. E., Goulden, M. L., Wang, Z., Barr, J. G., Schaaf, C., Brown, M., Fuentes, J. D., Göckede, M., and Black, A.: Radiative forcing of natural forest disturbances, Glob. Change Biol., 18, 555-565, 2012.

Oke, T. R.: Boundary Layer Climates, Routledge, 2nd edition, Methuen, London, vol. 8, 262-303, 1987.

Pomeroy, J. W. and Gray, D. M.: Saltation of snow, Water Resour. Res., 26-27, 1583-1594, 1990. 
Pomeroy, J. W., Marsh, P., and Gray, D. M.: Application of a distributed blowing snow model to the Arctic, Hydrol. Process., 11, 1451- 1464, 1997.

Pomeroy, J. W., Gray, D. M., Hedstrom, N. R., and Janowicz, J. R.: Prediction of seasonal snow accumulation in cold climate forests, Hydrol. Process., 16, 3543-3558, https://doi.org/10.1002/hyp.1228, 2003.

Raleigh, M. S., Landry, C. C., Hayashi, M., Quinton, W. L., and Lundquist, J. D.: Approximating snow surface temperature from standard temperature and humidity data: new possibilities for snow model and remote sensing evaluation, Water Resour. Res., 49, 8053-8069, https://doi.org/10.1002/2013WR013958, 2013.

Roth, T. R. and Nolin, A. W.: Willamette Water 2100 Forest Elevational Snow Transect (ForEST) Project: dataset available at https://ir.library.oregonstate.edu/xmlui/handle/1957/59984 (last access: 19 July 2017), https://doi.org/10.7267/N900001K, 2016.

Ryan, W. A., Doesken, N. J., and Fassnacht, S. R.: Evaluation of ultrasonic snow depth sensors for US snow measurements, J. Atmos. Ocean. Tech., 25, 667-684, https://doi.org/10.1175/2007JTECHA947.1, 2008.

Schmidt, R. A. and Gluns, D. R.: Snowfall interception on branches of three conifer species, Can. J. Forest Res., 21, 1262-1269, 1991.

Sicart, J. E., Essery, R. L. H., Pomeroy, J. W., Hardy, J., Link, T. E., and Marks, D.: A sensitivity study of daytime net radiation during snowmelt to forest canopy and atmospheric conditions, J. Hydrometeorol., 5, 774-784, https://doi.org/10.1175/15257541(2004)005<0774:ASSODN>2.0.CO;2, 2004.

Spracklen, D. V., Mickley, L. J., Logan, J. A., Hudman, R. C., Yevich, R., Flannigan, M. D., and Westerling, A. L.: Impacts of climate change from 2000 to 2050 on wildfire activity and carbonaceous aerosol concentrations in the western United States, J. Geophys. Res.-Atmos., 114, D20301, https://doi.org/10.1029/2008JD010966, 2009.

Sproles, E. A., Nolin, A. W., Rittger, K., and Painter, T. H.: Climate change impacts on maritime mountain snowpack in the Oregon Cascades, Hydrol. Earth Syst. Sci., 17, 2581-2597, https://doi.org/10.5194/hess-17-2581-2013, 2013.
Sproles, E. A., Roth, T. R., and Nolin, A. W.: Future snow? A spatial-probabilistic assessment of the extraordinarily low snowpacks of 2014 and 2015 in the Oregon Cascades, The Cryosphere, 11, 331-341, https://doi.org/10.5194/tc-11-3312017, 2017.

Stähli, M. and Gustafsson, D.: Long-term investigations of the snow cover in a subalpine semi-forested catchment, Hydrol. Process., 20, 411-428, 2006.

Storck, P., Lettenmaier, D. P., and Bolton, S.: Measurement of snow interception and canopy effects on snow accumulation and melt in a mountainous maritime climate, Oregon, United States, Water Resour. Res., 38, 1223, https://doi.org/10.1029/2002WR001281, 2002.

Varhola, A., Coops, N. C., Weiller, M., and Moore, R. D.: Forest canopy effects on snow accumulation and ablation: an integrative review of empirical result, J. Hydrol., 392, 219-233, https://doi.org/10.1016/j.jhydrol.2010.08.009, 2010.

Vose, J. M., Miniat, C. F., Luce, C. H., Asbjornsen, H., Caldwell, P. V., Campbell, J. L., Grant, G. E., Isaak, D. J., Loheide II, S. P., and Sun, G.: Ecohydrological implications of drought for forests in the United States, For. Ecol. Manage., 380, 335345, https://doi.org/10.1016/j.foreco.2016.03.025, 2016.

Westerling, A. L., Hildago., H. G., Cayan, D. R., and Swetnam, T. W.: Warming and earlier spring increase in western US forest wildfire activity, Science, 313, 940, https://doi.org/10.1126/science.1128834, 2006.

Westerling, A. L., Turner, M. G., Smithwick, E. A. H., Romme, W. H., and Ryan, M. G.: Continued warming could transform Great Yellowstone fire regimes by mid-21st century, P. Natl. Acad. Sci. USA, 108, 32, 13165-13170, 2011.

Woods, S., Ahl, R., Sappington, J., and McCaughey, W.: Snow accumulation in thinned lodgepole pine stands, Montana, USA, Forest Ecol. Manag. 235, 202-211, 2006. 